$\begin{array}{ll}\text { MINING AND METALLURGY INSTITUTE BOR } & \text { YU ISSN: 1451-0162 } \\ \text { COMMITTEE OF UNDERGROUND EXPLOITATION OF THE MINERAL DEPOSITS } & \text { UDK: } 622\end{array}$

UDK: $622.765 .061 .622 .343 /: .349(045)=20$

L. Valderrama ${ }^{*}$, Z. Petkovic $^{* *}$, J. Ossandon $^{*}$

\title{
PETKOM-30 REAGENT A NEW COLLECTOR FOR COPPER MINERALS
}

\begin{abstract}
This paper presents the results obtained with flotation reagents in comparison to conventional reagents, on flotation test's at laboratory level with minerals at the Plants. At the test's, collectors from those Plants were used and these new reagents, with a modification of the particle size distribution, Collector dosage and ph of the pulp. These new reagents achieve better metallurgical parameters regarding the standard collector, increasing the law of copper in the concentrate and recovery. Furthermore this reagent has a positive effect, since it is based on a mixture of salts 2mercaptobenzotiazol, has a reduced toxicity in compared to conventional reagents that causes a better impact on the environment.
\end{abstract}

Keywords: Petkom collectors, recovery, copper.

\section{SUMMARY}

The mining industry in Chile plays a fundamental role on the economy, since we are the leading producer of copper in the world, third in molybdenum, fifth in silver, fourteen in gold, in industrial minerals we are first in iodine and in lithium. We also contemplate other minerals as iron, manganese, lead, zinc and industrial minerals. The characteristics of these mining companies are mayor installations, which uses water, energy, natural resources and chemical products $[1,2]$.

The ore flotation is still one of the most important processes in the benefit of the minerals. This method has permitted economic ore exploitation of low law and of a complex mineralogical composition, which in other times would have been impossible to process.

The ore flotation is a concentration technique which takes advantage of the difference between superficial properties or interfacial of the minerals and the gangue. It's based on the adherence of some solids to gas bubbles generated in the slurry (pulp) by some external device, in the flotation cell. The air bubbles transport the solids to the surface where they are collected and recovered as concentrated. The fraction that doesn't adhere to

* Departamento de Metalurgia, Universidad de Atacama, Copiapó, Chile.

** Petkom S. A. 
the bubbles remains in the pulp and constitute the tailing. This way the condition of floatability is a strong adherence between the useful particles and the bubbles, which needs to be able to support the agitation and turbulence in the cell. These particles are meant to be hydrophobic, or water repellent, contrary to the particles that constitute the tailing, which are hydrophilic.

To be able to obtain a good concentration in the cleaning stage of the concentrate, it requires that the useful species that constitute the ore, are separated from each other or released, this liberation of the useful particles is not necessary in the primer step of flotation [3 ].

The flotation is an operation of several complex physical-chemical processes, based on the differences of free energy of the involved interfaces (solid/liquid, solid/gas and liquid/gas), in which the valuable minerals are separated from the gangue due to the differences in their hydrophobicity. In most floatation systems, the particles surface turns hydrophobic by the selective absorption of the surfactants called collectors. The hydrophobic particles are aerophilic and are recovered in the foam, while the hydrophilic particles remain suspended in the slurry and are discharged in the tailings.

The floatation effectiveness is significantly determined by the application of the collectors, which increase the hydrophobic surface of minerals, and therefore increases the affinity by the bubble air. For this reason, the ore floatation process is complex and needs to adjust properly the collector to be able to obtain a high selectivity [4].

Contrary to other concentration methods, in floatation it's possible to vary the difference between the useful properties and the gangue, modifying the chemical environment and the electrochemical of the system through a proper selection of the chemical reagents added, collectors, foaming agents, activators, depressants or Ph modifiers.

In this context the floatation reagents play an important role in the process, which by being fed to the flotation circuit, they achieve certain specific functions which makes possible the separation of the valuable minerals from the gangue. However the selection of reagents is not an easy task due to a number of technical difficulties presented during the process, like the mineralogical complexity of the ore among other aspects. Furthermore, the use of biodegradables reagents is without no doubt one of the necessary actions in the mining metallurgic industry, for which it needs to comply with the necessity of avoiding negative environmental impacts [5,6].

Copper minerals in Chile are flotated with xanthate type collectors. The mining companies have shifted to sustainability supported by the use of innovating and clean technologies. In this context, the new models of mining business, are not only trying to minimize the waste generation and effluents, but above all, regain the existing environmental liabilities and assuming a reagent flotation supply more atmosphere friendly.

The main object of this paper is to show the improvements produced by these new reagents of flotation. This way the performed flotation tests are focused on finding the advantages of the Petkom reagents, both in technical, environmental and economic aspects, regarding to metallurgy parameters of the standard reagents [6,7].

\section{EXPERIMENTAL DEVELOPMENT}

\subsection{Materials and equipments}

The Petkom 30 reagents are aqueous solutions of salts of 2-mercaptobenzothiazole, Limonac 1658 and water. It's a selective collector and a corrosion inhibitor for minerals of copper, gold and silver. It's a red- 
yellow color liquid, without any defined odour(smell), has an intensity between 1,20 to $1,22 \mathrm{~kg} / \mathrm{L}$ and is water-soluble. The mineral samples for the flotation tests were obtained in the industrial plant M.A Matta of the National Mining Company, COEMIN S.A and Mining Company Atacama Kozan.

These samples were ground below 20 meshes and quartered by the quartering and paleo method leaving samples of approximately 20 kilograms as witness; the other sample was homogenized through a quartering rifle until obtaining 1.300 grams of samples approximately.

A kinetic grinding system was made to determine the time of grinding of the mineral sample. This was made in a roller mill, with a percentage of pulp solid in the mill of $60 \%$ of solids.

The flotation tests were made in a Denver cell D-12. The pulp obtained from the milling is adjusted to a 2,7 litres of volume, with a specific weigh mineral of $3,6 \mathrm{~kg} / \mathrm{L}$, the percentage of solids for the flotation was $35 \%$ in solids. The reagents are added according to the company's standard proportion.

The products obtained were filtrated and dried at $90^{\circ} \mathrm{C}$ to avoid the sublimation of some of the elements, especially sulphur. Once dried they were weighed and registered, and then they were quartered to obtain a representative part of the sample sent to chemical analyze.

\subsection{STUDIED CASES}

\subsubsection{Manuel Antonio Matta Plant}

Flotation tests were made at laboratory level to analyze the behavior of the Petkom reagents against the reagents used at the industrial plant, before three different samples of sulphured mineral. For the test of the plant $25 \mathrm{~g} / \mathrm{t}$ of collector SF-323 was used and as foaming F-810 25 g/t. For the test's where Petkom collector was used it was of $30 \mathrm{~g} / \mathrm{t}$ and the same foaming $25 \mathrm{~g} / \mathrm{t}$.
Flotation test's were made besides, to analyze the decreased $\mathrm{pH}$ from the pulp and different dosages of the reagent Petkom $30(50 \mathrm{~g} / \mathrm{t}$ and $60 \mathrm{~g} / \mathrm{t})$ in front of the conventional reagent used at the Plant at pH 10, 5.

\subsubsection{Atacama Kozan}

Flotation test's were made at laboratory level to analyze the Petkom reagents behavior against the reagents used at the Plant with the object to analyze the $\mathrm{pH}$ of the pulp. The test's were made at a $\mathrm{Ph}$ of 8,5 and 9,5 with a dosage of Petkom of 50 and $60 \mathrm{~g} / \mathrm{t}$, trying to maintain the recovery of copper obtained at the Plant at $10,5 \mathrm{pH}$.

The conditions used were at a 5 minutes conditioning, 15 minutes of flotation, $35 \%$ percentage of solids, $60 \%$ of grading(particle size distribution)- 200 Tyler mesh.

\subsubsection{Coemin Plant}

The flotation test's made at laboratory level were made with a mineral from the Explorer and Explotation Chilean Mining Company- Rumanian COEMIN S.A. These rougher flotation test's had as objective to analyze the Petkom reagents in front of the actual used reagents at the Plant, that are $50 \mathrm{~g} / \mathrm{t}$ of isobutyl xanthate, $40 \mathrm{~g} / \mathrm{t}$ of ethyl xanthate and $23 \mathrm{~g} / \mathrm{t}$ of $\mathrm{MX}$ 7017.

\section{RESULTS AND DISCUSSION}

\subsection{A. M. Matta Plant}

The results obtained at the flotation test's to evaluate the behavior of the three processed minerals at M.A Matta Plant, are reagents used at the Plant and the Petkom reagent are shown on the following tables.

On table 1 , one can observe that on the test using the Plant's reagents, the recovery of copper reaches a total of $88,5 \%$ and $93,9 \%$ of insoluble copper. While with 
Petkom 30 reagent it was of $87,3 \%$ and of $93,2 \%$ of insoluble copper. When com-

paring the obtained law of concentrate, the one with Petkom reagent is greater.

Table 1. Results obtained with the reagents for mineral 1.

\begin{tabular}{|l|l|c|c|c|c|c|}
\hline & Flow & $\begin{array}{c}\text { Weith } \\
(\mathbf{g})\end{array}$ & $\begin{array}{c}\text { Law Cu} \\
\mathbf{( \% )}\end{array}$ & $\begin{array}{c}\text { Law Cu } \\
\mathbf{( \% )}\end{array}$ & $\begin{array}{c}\text { Rec. Cu} \\
\mathbf{( \% )}\end{array}$ & $\begin{array}{c}\text { Rec. Cu } \\
\mathbf{( \% )}\end{array}$ \\
\hline \multirow{3}{*}{ Plant } & \\
& Conc. & 140,0 & 9,96 & 9,96 & 88,5 & 93,9 \\
\cline { 2 - 7 } & Tailing & 1094,0 & 0,16 & 0,18 & 11,5 & 6,1 \\
\cline { 2 - 7 } & Feed. & 1234,0 & 1,27 & 1,20 & 100,0 & 100,0 \\
\hline \multirow{3}{*}{ Petkom } & Conc. & 130,0 & 10,52 & 10,52 & 87,3 & 93,2 \\
\cline { 2 - 7 } & Tailing & 1104,0 & 0,18 & 0,09 & 12,7 & 6,8 \\
\cline { 2 - 7 } & Feed. & 1234,0 & 1,27 & 1,19 & 100,0 & 100,0 \\
\hline
\end{tabular}

Table 2 presents the results obtained with the reagent used at the Plant and the one tested for mineral 2 . One observe that the recovery of the total copper is of 95,8\%, the insoluble copper is of $97,8 \%$. The same table shows that when Petkom 30 reagent was used, the recovery was greater of the total copper and of insoluble copper. Regarding to the law of the obtained concentrates, with the Petkom reagent an increase of $0,96 \%$ of copper is produced.

Table 2. Results obtained with the reagents for mineral 2.

\begin{tabular}{|l|l|c|c|c|c|c|}
\hline \multirow{3}{*}{ Flow } & $\begin{array}{c}\text { Weith } \\
(\mathbf{g})\end{array}$ & $\begin{array}{c}\text { Law Cu} \\
\mathbf{( \% )}\end{array}$ & $\begin{array}{c}\text { Law Cu} \\
\mathbf{( \% )}\end{array}$ & $\begin{array}{c}\text { Rec. Cu} \\
\mathbf{( \% )}\end{array}$ & $\begin{array}{c}\text { Rec. } \mathbf{C u}_{\text {ins }} \\
\mathbf{( \% )}\end{array}$ \\
\hline \multirow{3}{*}{ Plant } & Conc. & 125,0 & 14,46 & 14,46 & 95,8 & 97,8 \\
\cline { 2 - 7 } & Tailing & 1117,0 & 0,07 & 0,04 & 9,2 & 2,2 \\
\cline { 2 - 7 } & Feed. & 1242,0 & 1,52 & 1,49 & 100,0 & 100,0 \\
\hline \multirow{3}{*}{ Petkom } & Conc. & 1126,0 & 15,42 & 15,42 & 96,8 & 98,4 \\
\cline { 2 - 7 } & Tailing & 116,0 & 0,05 & 0,03 & 3,2 & 1,6 \\
\cline { 2 - 7 } & Feed. & 1242,0 & 1,49 & 1,47 & 100,0 & 100,0 \\
\hline
\end{tabular}

On table 3, one can observe results obtained for mineral 3. The recovery reached a value of $88,9 \%$ and $94,9 \%$ of insoluble copper. The same mineral but using reagent
Petkom, the reached recovery was of $87,8 \%$ and $93,8 \%$ of insoluble copper. The law of the concentrate obtained is greater than $1,17 \% \mathrm{Cu}$.

Table 3. Results obtained with the reagents for mineral 3.

\begin{tabular}{|c|c|c|c|c|c|c|}
\hline & Flow & $\begin{array}{l}\text { Weith. } \\
\text { (g) }\end{array}$ & $\begin{array}{c}\text { Law } \mathbf{C u} \mathbf{u}_{\mathrm{T}} \\
(\%)\end{array}$ & $\begin{array}{c}\text { Law } \mathrm{Cu}_{\text {ins. }} . \\
(\%)\end{array}$ & $\begin{array}{c}\text { Rec. } \mathrm{Cu}_{\mathrm{T}} \\
(\%)\end{array}$ & $\begin{array}{c}\text { Rec. } C u_{\text {ins }} \cdot \\
(\%)\end{array}$ \\
\hline \multirow{3}{*}{ Planta } & Conc. & 153,0 & 11,02 & 11,02 & 88,9 & 94,9 \\
\hline & Tailing & 1082,0 & 0,20 & 0,09 & 11,1 & 5,1 \\
\hline & Feed. & 1235,0 & 1,54 & 1,44 & 100,0 & 100,0 \\
\hline \multirow{3}{*}{ Petkom } & Conc. & 1098,0 & 12,19 & 12,19 & 87,8 & 93,8 \\
\hline & Tailing & 136,0 & 0,21 & 0,10 & 12,2 & 6,2 \\
\hline & Feed. & 1234,0 & 1,53 & 1,43 & 100,0 & 100,0 \\
\hline
\end{tabular}


Figure 1 shows the results of recovery and law of copper in the concentrate obtained in the tests to evaluate the dosage of Petkom at pH 9,5.

One observe on the figure that on both test's using Petkom one obtain greater recoveries (94,8\% and 90,8\% respectively) as well the law of copper in the concentrate
(10,45\% and 12,64\%), when i reagents used at the Plant (recovery of $90,4 \%$ and $7,21 \%$ of copper) This shows that is possible to obtain concentrates with laws and greater recoveries than the obtained at a $\mathrm{pH}$ of 10,5 using the reagents of the Plant, with a considerable decreased of lime, which implies a minor cost of operation in the process.

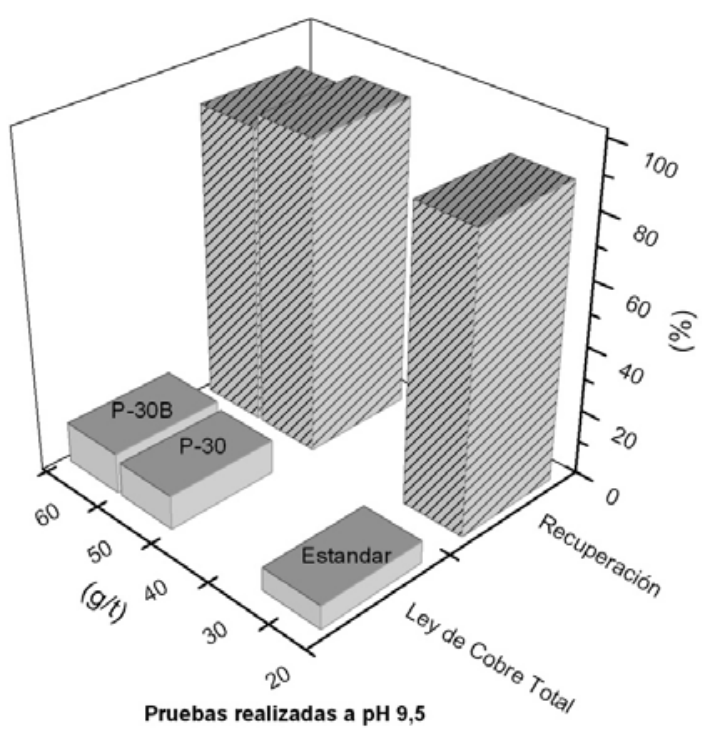

Fig. 1. Effect of the dose of reagent and ph of the recovery and law of concentrate.

\subsection{Atacama Kozan}

Figure 2 presents the recovery and law of copper in the concentrate versus the dosage of the reagent Petkom to a granulometry (particle size distribution) of $60 \%$ below the 200 mesh to a $\mathrm{pH}$ of 8,5 compared to the test with the reagents used in the Plant that were made at a $\mathrm{pH}$ of 10,5 and $70 \%$ below the 200 mesh.

One observe on the figure that the recovery obtained with the reagent Petkom are similar to the obtained with the reagent used at the Plant of Atakama Kozan for concentrates of $50 \mathrm{~g} / \mathrm{t}$ and $60 \mathrm{~g} / \mathrm{t}$ (93,3\% and $93,5 \%$ against a $93,8 \%$ ) According to the law of copper in the concentrate one can observe that on the two test's made with the reagent Petkom, they are higher than with the reagent used on the Plant, for the dosage of $50 \mathrm{~g} / \mathrm{t}$ and $60 \mathrm{~g} / \mathrm{t}$ the law of copper on the concentrate is of $8,94 \%$ and $8,2 \%$, while for the standard test, the law of copper obtained is of $6,6 \%$. 


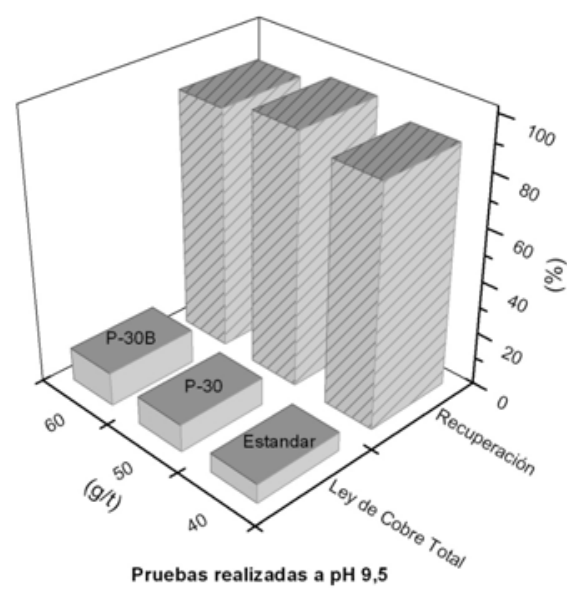

Fig. 2. Effect of the reagent dosage and $\mathrm{pH}$ of the recovery and law of concentrate.

Figure 3 presents the recovery and law of copper in the concentrate versus the reagent Petkom dosage to a granulometry(particle size distribution) of $60 \%$ below the mesh 200 at a 9,5 $\mathrm{pH}$, compared with the test where reagents of the Plant were used at a pH of 10,5 and $70 \%$ below mesh 200 .
One observe on the figure that the recovery obtained with reagent Petkom are similar to the obtained with the reagent used at the Atacama Kozan Plant (96,3\% and 92,4\% against a 93,8\%). The law of copper on the obtained concentrates, with the reagent Petkom these are pretty higher (9, 34\% and 10, $57 \%$ against a $6,6 \%$ of copper)

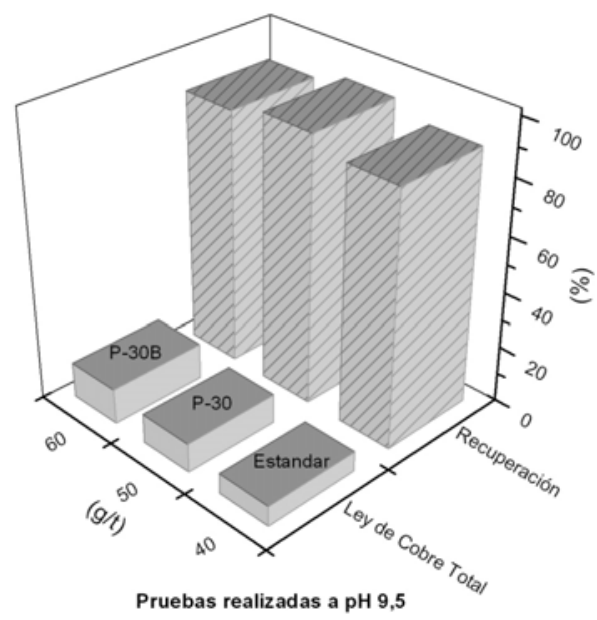

Fig. 3. Effect of the reagent dosage and $\mathrm{pH}$ on the recovery and law of concentrate. 


\subsection{Coemin Plant}

Table 7 presents the results obtained on the flotation test using the Plant's reagent's. One can observe that the law of

copper on the obtained concentrates reaches a value of $9,58 \%$ and the recovery obtained is of $97,2 \%$.

Table 7. Test results made with the Plant's reagents.

\begin{tabular}{|l|c|c|c|}
\hline \multicolumn{1}{|c|}{ Flow } & Weith $(\mathrm{g})$ & Law $\mathrm{Cu}_{\mathrm{T}}(\%)$ & Rec. $\mathrm{Cu}_{\mathrm{T}}(\%)$ \\
\hline Feeding. & 1167 & 1,24 & 100,0 \\
\hline Concentrate & 147,6 & 9,58 & 97,2 \\
\hline Tailing & 1019,4 & 0,041 & 2,8 \\
\hline
\end{tabular}

Table 8. Mass results and law obtained with the Petkom reagents.

\begin{tabular}{|l|c|c|c|}
\hline \multicolumn{1}{|c|}{ Flow } & Weith $(\mathrm{g})$ & Law $\mathrm{Cu}_{\mathrm{T}}(\%)$ & Rec. $\mathrm{Cu}_{\mathrm{T}}(\%)$ \\
\hline Feeding. & 1167 & 1,24 & 100,0 \\
\hline Concentrate & 125,8 & 10,97 & 95,2 \\
\hline Tailing & 1041,2 & 0,067 & 4,8 \\
\hline
\end{tabular}

On table 9 the results of the flotation test's are presented with the Petkom reagents, varying the dosage of the collector. The results show that the recovery and the law on the concentrates obtained are greater than the ones obtained with the reagents used at the Plant as the dosage of the collector is increased.

Table 9. Mass Results and obtained laws.

\begin{tabular}{|l|l|c|c|c|}
\hline Dosage & \multicolumn{1}{|c|}{ Flow } & Weith $\mathbf{( g )}$ & Law $\mathbf{C u}_{\mathbf{T}} \mathbf{( \% )}$ & Rec. $\mathbf{C u}_{\mathbf{T}} \mathbf{( \% )}$ \\
\hline \multirow{3}{*}{$30 \mathrm{~g} / \mathrm{t}$} & Concentrate & 128,9 & 10,70 & 95,1 \\
\cline { 2 - 5 } & Tailing & 1038,1 & 0,07 & 4,9 \\
\cline { 2 - 5 } & Feeding. & 1167 & 1,24 & 100,0 \\
\hline \multirow{3}{*}{$35 \mathrm{~g} / \mathrm{t}$} & Concentrate & 125,7 & 11,22 & 97,3 \\
\cline { 2 - 5 } & Tailing & 1041,7 & 0,05 & 2,7 \\
\cline { 2 - 5 } & Feeding. & 1167 & 1,24 & 100,0 \\
\hline \multirow{3}{*}{$40 \mathrm{~g} / \mathrm{t}$} & Concentrate & 120,6 & 11,68 & 97,1 \\
\cline { 2 - 5 } & Tailing & 1046,4 & 0,04 & 2,9 \\
\cline { 2 - 5 } & Feeding. & 1167,0 & 1,24 & 100,0 \\
\hline
\end{tabular}

The results of the flotation test's varying the $\mathrm{pH}$ of the pulp between 10,5; 10,0 and 9,0 are shown on figure 4 . One observe that at $\mathrm{pH} 10,5$ the recovery is of $97,5 \%$ and the law of copper in the con- centrate is of $11,53 \%$, these values decreases as the $\mathrm{pH}$ descend reaching a recovery of 94,1 and a law of concentrate of $9,82 \%$ at a pH of 9 . 


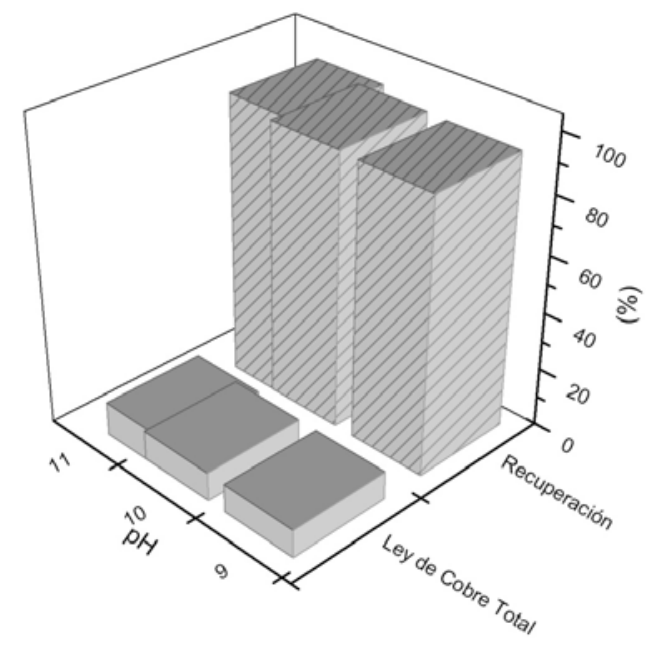

Fig. .The effect of the $\mathrm{pH}$ on the recovery and law of the concentrate.

\section{CONCLUSIONS}

Based on the results obtained at the flotation test's with the minerals of the Plants M.A Matta, Coemin and Atacama Kozan one can conclude the following.

- The Petkom 30 reagent can replace the actual reagents used in the copper mineral flotation used at these Plants.

- After comparing the results, one can observe that under the same conditions of quality operation of the obtained concentrates they are mayor with the Petkom reagent than with the actual used at the three Plants.

- On the tests made, the characteristic of corrosion inhibitor of Petkom reagent was not analyzed.

\section{BIBLIOGRAHY}

[1] http://minerals.usgs.gov/minerals/pubs/ commodity/

[2] http://www.sernageomin.cl/pdf/ mineria/estadisticas/anuario/anuario 20 11.pdf
[3] N. P. Finkelstein. The activation of sulfide minerals for flotation: a review. Int. J. Miner. Process. 52 (1997), pp. 81-120

[4] A. P. Chaves. Teoria e prática do tratamento de minérios: A flotação no Brasil. V.4, 2ªd., Brasil, 2009.

[5] A. M. Marabini, M. Barbaro, V. Alesse. New reagents in sulphide mineral flotation. Int. J. Miner. Process., 33 (1991), pp 1-396. 1991.

[6] V. I. Klassen, V. A. Mokrousov. An introduction to the theory of flotation. pp 493 pp. 1963.

[7] L. Valderrama, Z. Petkovic, I. Rajevic. SKIK- PETKOM Selective Collectors and Corrosion Inhibitors for NonFerrous Ores. XXI International Serbian Symposium on Mineral Processing. Bor, Serbia, pp. 262 - 270, 2008. 